\title{
PEMBERDAYAAN MASYARAKAT MELALUI DIVERSIFIKASI OLAHAN DAUN KELOR
}

\author{
Community Empowerment through Moringa Processing Diversification
}

\author{
Miftahul Hasanah ${ }^{1 *}$, Evia Riska Fitriana ${ }^{1)}$, Novia Indriati ${ }^{1)}$, Siti Masruroh ${ }^{1)}$, \\ Sulastri $^{2)}$, Cahyuni Novia ${ }^{3)}$, \\ ${ }^{1}$ Mahasiswa S1 Program Studi Informatika, Universitas Nurul Jadid Probolinggo \\ email: hasanahm341@gmail.com \\ ${ }^{2}$ Mahasiswa S1 Program Studi Teknik Elektro, Universitas Nurul Jadid Probolinggo \\ email: nonlastrii5@gmail.com \\ ${ }^{3}$ Pengajar Program Studi Informatika,Universitas Nurul Jadid Probolinggo \\ email:vhie771108@gmail.com
}

\begin{abstract}
Sumbercenteng Village is a village located in Kotaanyar Sub-district of Probolinggo Regency of East Java Province. The inhabitants are mostly farmers. Moringa is one of plants that are easily found in community homes. It owns a lot of nutrition inside, unfortunately the community do not optimize the use of Moringa itself. The goal to be achieved in community service activities is to increase the income of the community groups of PKK mothers through the processing of various processed moringa into bakpia, nugget, and noodles. The method is done by using lecture and demonstration method along with training materials, and delivered directly by performing a presentation related to the process of making bakpia, nugget, and noodles ranging from raw materials, how to use the tools of production, the process of mixing the materials, cooking until packaging. The results of the whole $100 \%$ of partners can make a variety of processed moringa and can do the packaging well.
\end{abstract}

Keywords: Moringa leaves, Moringa bakpia, Moringa nuggets, Moringa noodles

\begin{abstract}
ABSTRAK
Sumbercenteng adalah sebuah desa yang terletak di Kecamatan Kota anyar Kabupaten Probolinggo Propinsi Jawa Timur. Sebagian besar penduduknya berprofesi sebagai petani. Tanaman kelor merupakan salah satu tanaman yang mudah dijumpai di rumahrumah warga sekitar. Terdapat banyak kandungan nutrisi pada daun kelor, sayangnya masyarakat setempat tidak memanfaatkannya secara maksimal. Oleh karena itu, tujuan yang ingin dicapai dalam kegiatan pengabdian kepada masyarakat ini adalah meningkatkan pendapatan masyarakat kelompok ibu-ibu PKK dengan memanfaatkan diversifikasi aneka olahan daun kelor menjadi bakpia kelor, nugget kelor dan mie kelor. Metode yang dilakukan dengan menggunakan metode ceramah dan demonstrasi disertai materi pelatihan, serta disampaikan langsung dengan melakukan pendemonstrasian yang berkenaan dengan proses pembuatan bakpia, nugget, dan dimulai dari penanganan bahan baku, cara penggunaan alat-alat produksi, proses pencampuran bahan, pemasakan sampai pengemasan. Hasil secara keseluruhan hampir $100 \%$ mitra kerja dapat membuat aneka olahan daun kelor serta dapat melakukan pengemasan dengan baik.
\end{abstract}

Kata kunci : daun kelor, bakpia kelor, nugget kelor, mie kelor

PENDAHULUAN

Sumbercenteng adalah sebuah desa yang terletak di Kecamatan Kota anyar
Kabupaten Probolinggo Propinsi Jawa Timur. Sebagian besar penduduknya berprofesi sebagai petani karena kondisi 
wilayahnya yang masih asri dengan bentangan sawah di hampir segala penjurunya. Dengan potensi alam yang begitu besar, warga setempat bahkan dapat bercocok tanam di pekarangan rumahnya. Salah satu tanaman yang sering ditemui di Desa Sumbercenteng adalah tanaman kelor. Tanaman kelor biasa dimanfaatkan untuk sayur pelengkap makanan penduduk seharihari. Kurangnya pengetahuan masyarakat tentang diversifikasi beberapa olahan makanan berbahan dasar daun kelor menjadi faktor kurang menariknya mengkonsumsi daun kelor bagi masyarakat.

Moringa oleifera atau yang biasa disebut tanaman kelor merupakan tanaman multiguna yang memiliki sumber protein tinggi (Kurniasih, 2017), sedangkan daun kelor (Moringa oleifera) merupakan sumber bahan makanan yang memiliki nilai gizi tinggi (Minantyo et al., 2019).) Kandungan gizi daun kelor kering mengandung lebih dari 40 antioksidan alami (Mahmood 2010), protein $26,2 \mathrm{~g}$, kalsium $2.095 \mathrm{mg}$, besi 27.1 $\mathrm{mg}$, dan $\beta$-karoten $16800 \mathrm{mg}$ (Dachana et al. 2010).

Daun kelor (Moringa oleifera) memiliki fungsi yang sangat baik terhadap kesehatan seperti anti-hipertensi, antikanker dan antimikroba (Evivie et al., 2015; Leone et al., 2015). Penggunaan tepung daun kelor dapat digunakan sebagai prevensi untuk penyakit diabetes mellitus (Munim et al., 2019). Serbuk daun kelor berperan dalam memperbaiki sistem imun dan kandungan zat-zat bioaktif kelor yang telah dianalisa adalah beta carotene yang berfungsi sebagai phagocitotic activity (Lutfiah, 2012).

Kelor dapat dimanfaatkan untuk subtitusi pembuatan brownies kelor, kerupuk kelor, dan pia kelor (Lestari dan Sari, 2019). Daun kelor dimanfaatkan sebagai subtitusi dalam pembuatan kukis (Yuniarsih et al., 2019) dan mie basah. Substitusi tepung terigu dengan tepung daun kelor dalam pembuatan mie basah dapat meningkatkan mutu mie basah dari segi gizi, fisik, dan organoleptik (Rahmi et al., 2019). Penambahan tepung daun kelor dalam pembuatan mie basah yang berbahan terigu dapat meningkatkan kadar protein (Zakaria et al., 2016). Pembuatan mie kering dengan penambahan serbuk daun kelor dapat menghasilkan lemak 0,29\%, protein 6,83\%, dan karbohidrat 69,36\% (Nabila dan Marpaung, 2017). Peningkatan protein juga terjadi pada mie mocaf yang disubtitusikan daun kelor (Trisnawati dan Nisa, 2015)

Permasalahan utama masyarakat di

Desa Sumbercenteng adalah belum mengenal teknologi pengolahan daun kelor. Sebagian besar masyarakat hanya memanfaatkan daun kelor sebagai pelengkap dalam masakan sehari-hari bahkan tidak sedikit yang menjadikan daun kelor hanya sebagai tanaman hias yang dibiarkan melekat pada pekarangan rumah mereka, selain itu di beberapa wilayah di Indonesia pemanfaatan daun kelor lebih banyak dimanfaatkan untuk memandikan jenazah, meluruhkan jimat, dan sebagai pakan ternak. Hal ini terjadi karena ketidak pahaman masyarakat setempat tentang jenis produk lain yang dapat dihasilkan dari bahan baku daun kelor, masyarakat juga belum memahami teknologi sederhana yang dapat diaplikasikan pada daun kelor yang banyak dijumpai di halaman rumah mereka. Mereka beranggapan bahwa daun kelor hanya bisa dikonsumsi secara langsung tanpa diolah sama sekali. Padahal hanya dengan sentuhan teknologi yang sederhana daun kelor dapat menjadi produk olahan yang bernilai tinggi dibandingkan dengan menjual dalam bentuk belum diolah. Salah satunya adalah mengolah daun kelor menjadi bakpia, nugget dan mie.

Permasalahan lainnya adalah kurangnya kepedulian masyarakat terhadap perkembangan teknologi dan lambannya akses informasi yang masuk kepedesaan membuat masyarakat ketinggalan informasi-informasi penting yang telah dan sedang berkembang, termasuk informasi penting mengenai teknologi tepat guna sederhana yang dapat diterapkan pada kehidupan sehari-hari. Selain itu tingkat pendidikan juga berpengaruh terhadap pola 
pikir kehidupan masyarakat sehingga kreasi-kreasi baru sulit mereka ciptakan dan dikembangkan. Sarana dan prasarana yang kurang, letak yang jauh dari kota juga merupakan suatu hambatan dalam penerimaan teknologi terbaru. Kenyataan inilah yang terjadi pada seluruh masyarakat pedesaan termasuk masyarakat desa Sumbercenteng, Kecamatan Kotaanyar, Kabupaten Probolinggo.

\section{BAHAN DAN METODE}

\section{Bahan}

Bahan baku pembuatan bakpia kelor meliputi; serbuk kelor, tepung terigu, susu bubuk, garam, kacang hijau, tepung tapioka, minyak goreng, vanili dan air hangat. Bahan baku pembuatan nugget kelor, yaitu; serbuk kelor, daging ayam, bawang putih, bawang bombai, tepung terigu, tepung tapioka, susu cair, telur, merica bubuk, garam dan tepung roti. Sedangkan bahan baku pembuatan mie kelor meliputi; bubuk kelor, tepung terigu, tepung tapioka, telur, air dan garam.

\section{Alat}

Alat yang digunakan adalah baskom, gilingan adonan, timbangan, gelas ukur, plastik bako, loyang, oven, gilingan mie, gilingan daging, sealer, dandang, kompor, pisau, telenan, sutil, bak penampungan bahan, wajan, sendok pengaduk, nampan cetakan, serbet, dan plastik kemasan.

\section{Metode / Pelaksanaan penelitian}

Metode pengumpulan data dilakukan dengan melakukan wawancara dan pemberian kuesioner pada anggota PKK dan masyarakat. Pengumpulan data ini dimaksudkan untuk mengetahui status sosial, pendidikan dan motivasi mitra kerja dalam kegiatan PKM yang dilaksanakan agar target luaran dapat tercapai. Target luaran dinilai pada saat pelaksanaan kegiatan praktek pembuatan bakpia kelor, nugget kelor, mie kelor dan pemantauan keberlanjutan kegiatan dengan memanfaatkan media sosial sebagai sarana promosi produk.

\section{HASIL DAN PEMBAHASAN}

Hasil pelaksanaan kegiatan Program Kreativitas Mahasiswa Bidang Pengabdian Kepada Masyarakat melibatkan kelompok PKK Desa Sumbercenteng Kecamatan Kotaanyar Kabupaten Probolinggo. Mitra kerja yang ikut dalam kegiatan pelatihan pembuatan produksi dan pengemasan adalah 30 orang dengan distribusi pendidikan6 orang Sarjana, 10 orang SMU, 9 orang SMP dan 5 orang SD. Secara umum, pendidikan mitra kerja cukup baik dan data yang ditemui menunjukkan bahwa tidak ada seorang pun dari peserta yang pernah mengetahui cara pembuatan bakpia kelor, nugget kelor dan mie kelor.

Rendahnya pengetahuan mitra kerja tentang diversifikasi aneka olahan kelor dengan berlimpahnya tanaman kelor di Desa Sumbercenteng merupakan suatu hal yang menarik perhatian anggota tim PKM untuk memberikan penyuluhan dan pelatihan terkait diversifikasi aneka olahan kelor.

Tabel 1. Mitra kerja yang pernah membuat bakpia kelor, nugget kelor, dan mie kelor sebelum kegiatan PKM

\begin{tabular}{lccc}
\hline & $\begin{array}{c}\text { Bakpi } \\
\mathrm{a}\end{array}$ & $\begin{array}{c}\text { Nugge } \\
\mathrm{t}\end{array}$ & Mie \\
\hline Pernah & 0 & 0 & 0 \\
Belum pernah & 30 & 30 & 30 \\
Jumlah & 30 & 30 & 30 \\
\hline
\end{tabular}

Tabel 2. Produk yang dihasilkan menarik, dapat dikembangkan dan bernilai jual

\begin{tabular}{lccc}
\hline & $\begin{array}{c}\text { Bakpi } \\
\text { a }\end{array}$ & Nugget & Mie \\
\hline Ya & 30 & 30 & 30 \\
Tidak & 0 & 0 & 0 \\
Jumlah & 30 & 30 & 30 \\
\hline
\end{tabular}

Tabel 3. Kegiatan yang dilakukan bermanfaat dan berpotensi untuk dilanjutkan

\begin{tabular}{cccc}
\hline & Bakpia & Nugget & Mie \\
\hline Ya & 30 & 30 & 30
\end{tabular}




\begin{tabular}{lccc} 
Tidak & 0 & 0 & 0 \\
Jumlah & 30 & 30 & 30 \\
\hline
\end{tabular}

Mitra kerja yang berjumlah 30 orang belum pernah membuat bakpia kelor, nugget kelor dan mie kelor (Tabel 1). Setelah melaksanakan kegiatan, ternyata seluruh mitra kerja dapat membuat semua olahan produk dengan baik yaitu secara tampilan dan kualitas rasa bakpia, nugget dan mie menarik, sehingga dapat dikembangkan secara mandiri oleh PKK Sumbercenteng sebagai produk olahan dari daun kelor (Tabel 2). Kondisi produk akan lebih menarik dan ketahanan produk meningkat dengan dilakukan pengolahan dan pengemasan yang benar.

Peralatan pengemasan yang dimiliki mitra kerja menjadi modal penting dalam pengembangan produk dan peningkatan nilai jual bakpia kelor, nugget kelor dan mie kelor. Dasar dalam pengembangan produk yaitu bahan dasar daun kelor yang sangat mudah didapatkan di desa Sumbercenteng. Mitra kerja beranggapan bahwa kegiatan yang telah dilaksanakan cukup bermanfaat bagi mitra kerja (Tabel 3).

\section{KESIMPULAN}

Kesimpulan dari kegiatan PKM yang telah dilakukan diantaranya adalah:

1. Seluruh mitra kerja dapat membuat aneka olahan daun kelor serta melakukan pengemasan dengan baik.

2. Produk aneka olahan daun kelor yang dihasilkan pada pelatihan produksi menarik dan dapat dikembangkan.

3. Kegiatan yang dilakukan sangat bermanfaat bagi mitra kerja.

\section{UCAPAN TERIMA KASIH}

Penulis mengucapkan terima kasih kepada seluruh pihak yang telah membantu dalam pelaksanaan kegiatan PKM dan seluruh pihak yang telah membantu dalam penelitian ini terutama kepada Kemenristekdikti, Universitas Nurul Jadid, dan Kelompok Ibu-ibu PKK Desa Sumbercenteng Kabupaten Probolinggo.

\section{DAFTAR PUSTAKA}

Dachana KB, Rajiv J, Indrani D, \& Prakash J. (2010). Effect of dried moringa (Moringa oleifera Lam) leaves on rheological microstructural, nutritional, textural, and organoleptic characteristics of cookies. $J$ Food Quality 33: 660-677

Evivie, S. E, Ebabhamiegbebho, P. A, Imaren, J. and Igene, J. (2015). Evaluating the organoleptic properties of soy meatballs (beef) with varying levels of Moringa oleifera leaf powder. Journal of Applied Science and Environmental Management 19(4): 649-656.

Kuniasih. (2017). Khasiat \& dan manfaat daun kelor. Jakarta: PB

Leone, A., Fiorillo, G., Criscuoli, F., Ravasenghu, S., Santagostini, L., Fico, G., Spadafranca, A., Battezzati, A., Schiraldi, A., Pozzi, F., di Lello, S., Filippini, S. and Bertoli, A. (2015). Nutritional characterization and phenolic profiling of Moringa oleifera leaves grown in Chad, Sahrawi Refugee Camps, and Haiti. International Journal of Molecular Sciences 16: 18923-18937

Lestari, A. F., \& Sari, I. P. (2019). Kelor (kelas entrepreneurship pemanfaatan daun kelor) sebagai upaya pemberdayaan untuk meningkatkan produktivitas ibu rumah tangga. Jurnal Kesmas Untika Luwuk: Public Health Journal, 9(2), 1429-1444.

Lutfia, F., (2012), Potensi Gizi Daun Kelor (Moringa oleifera) Nusa Tenggara Barat, Media Bina Ilmiah, 6 (2), 4250.

Mahmood, K.T., Mugal, T., \& Haq, I.U. (2010). Moringa oleifera: a natural gift-A review. J Pharm Sci Res 2(11): 775-781. 
Minantyo, H., Purnomo, H., Winarno, P. S., \& Kartikawati, M. (2019). The improvement of nutrition quality and organoleptic characteristics of Indonesian milkfish meatball by adding kelor (Moringa oleifera Lam) leaves. International Food Research Journal, 26(1), 263-268.

Munim, A., Alwi, M. K., \& Syam, A. (2019). Pengaruh pemberian tepung daun kelor (moringa oleifera) terhadap penurunan glukosa darah pada penderita pradiabetes di wilayah kerja puskesmas samata kab. gowa. Jurnal Ilmiah Kesehatan Diagnosis, 13(6), 605-611.

Nabila, A. \& Marpaung, C. (2017). Pembuatan Mie dengan Campuran Serbuk Daun Kelor (Moringa oliefera L.). Surakarta: Universitas Sebelas Maret Surakarta;.

Rahmi, Y., Wani, Y. A., Kusuma, T. S., Yuliani, S. C., Rafidah, G., \& Azizah,
T. A. (2019). Profil Mutu Gizi, Fisik, dan Organoleptik Mie Basah dengan Tepung Daun Kelor (Moringa Oleifera). Indonesian Journal of Human Nutrition, 6(1), 10-21.

Trisnawati, M, \& Nisa F. (2015). Pengaruh penambahan konsentrat protein daun kelor dan karagenan terhadap kualitas mie kering tersubstitusi mocaf. $J$ Pangan dan Agroindustri. 3 (1): 23747.

Yuniarsih, E., Adawiyah, D. R., \& Syamsir, E. (2019). Karakter Tepung Komposit Talas Beneng dan Daun Kelor pada Kukis. Jurnal Mutu Pangan (Indonesian Journal of Food Quality), 6(1), 46-53.

Zakaria, Nursalim, \& Tamrin, A. (2016). Pengaruh Penambahan Tepung Daun Kelor terhadap Daya Terima dan Kadar Protein Mie Basah. Media Gizi Pangan $21 \quad$ (1): 73-8. 